\title{
ANTHROPOGENIC LANDFORM EVOLUTION REMOTED BY SATELLITE IMAGES IN TUUL RIVER BASIN
}

\author{
Davaagatan Tuyagerel $^{1}$, Alexander Orkhonselenge ${ }^{2^{*}}$
}

\begin{abstract}
${ }^{I}$ Division of Physical Geography, Institute of Geography and Geoecology, Mongolian Academy of Sciences, Ulaanbaatar 14200, Mongolia ${ }^{2}$ Laboratory of Geochemistry and Geomorphology, School of Arts and Sciences, National University of Mongolia. Ulaanbaatar 14201. Mongolia

*Corresponding author. Email: rkhnslng@num.edu.mn
\end{abstract}

\section{ARTICLE INFO}

Article history:

Received 25 June 2018

Accepted 26 December 2018

\begin{abstract}
Industrialization, construction and transportation network are abruptly grown and urban infrastructure is densely expanded due to rapid population growth, i.e., urbanization process is notably intensive in Ulaanbaatar as like as other cities in the world. Human activity in the overpopulated city distinctly modifies landforms and antipathetically impacts on the environment. Channel, floodplain and terraces of Tuul River draining through Ulaanbaatar have been strongly affected by the human activity. Reduction in water resource and water pollution of Tuul River are caused by bio-waste, solid waste and wastewater released from industries, thermal and electric power stations, constructions and companies operating along the river beach. This study presents landform evolution induced by human activity in Tuul River basin. More investigation is needed to infer anthropogenic landform evolution in large river basins in Mongolia based on field works and analytic measurements with further study.
\end{abstract}

Keywords: Anthropocene, fluvial geomorphology, drainage basin, Northern Mongolia

\section{INTRODUCTION}

Anthropogenic morphology is a quite new field in the Quaternary Science, especially Holocene environmental study, i.e., it is a combined scientific branch of Anthropocene and Geomorphology. It studies landform evolution induced by human activity rivaling the great geological forces (Brown et al., 2016; Veland and Lynch, 2016; Syvitski, 2018). Because rapid humanity's impact on the planet is recently strengthening geologists, geochronologists and geomorphologists to classify a new epoch, Anthropocene concept following the Holocene epoch.

Numerous effort to propose the new Anthropocene epoch are being completed by mostly geologists (e.g., Brown et al., 2016; Zalasiewicz et al., 2017; Waters et al., 2018).

(C) The Author(s). 2018 Open access This article is distributed under the terms of the Creative Commons Attribution 4.0 International License (https://creativecommons.org/licenses/by/4.0/), which permits unrestricted use, distribution, and reproduction in any medium, provided you give appropriate credit to the original author(s) and source, provide a link to the Creative Commons license, and indicate if changes were made. 
Human footprints are a key indicator of the Anthropocene (Tarolli et al., 2014; Bai et al., 2016; Zalasiewicz et al., 2016; Biermann et al., 2016; Brondizio et al., 2016; Verburg et al., 2016; Waters et al., 2016; Williams et al., 2016; Lockie, 2017; Gałuszka et al., 2017). For instance, Syvitski (2018) noted that a pervasive and persistent signature on Earth left by human activity combined with the substantial modification on carbon, nitrogen, and phosphorus cycles over the past century render the Anthropocene stratigraphically distinct from the Holocene and earlier epochs. There is a lack of such studies focusing on how human activity affects in environmental objects such as water quality and resource, air quality, soil productivity, and others in Mongolia except for a few results by Fernández-Giménez et al. (2017). Present study is the first effort to estimate anthropogenic landform change in Tuul River basin.

Understanding local landform changes is important to infer regional geomorphic evolution and to provide further predictions in the evolution. In the Anthropocene landform has been forced to shift by human impact. Therefore, consideration in anthropogenic effect on the landforms in drainage basins is necessary in order not to infer precise geomorphic evolution in local level, but to lead to make policy in water protection and to control water pollution and water resource in regional level. In recent years landform evolution induced by human activity have been abruptly risen. The landforms are shifted by abrupt increase in mining and industrialization and most of which result in channel's modification, pollution of surface water, reduction in water resource, and losses of biomass and soil profiles. The anthropogenic processes are widespread in large river basins. One of the large rivers affected by anthropogenic strength is Tuul River basin.

Tuul River basin is located in the northeast of Mongolia (Fig. 1). Head of Tuul River is a confluence of Namiya and Nergui Rivers draining from southern slopes of the Mt. Chisaalain Saridag and Mt. Shorootiin Davaa, branch mountains of the Khentii Mountain Range, uplifted at $2000 \mathrm{~m}$ a.s.l. Tuul River feeds Orkhon River which drains into Selenge River, a main headwater of Lake Baikal, the deepest freshwater lake in the world (National Atlas, 2009). Tuul River is fed by more than ten rivers draining from Khentii Mountain Range (Fig. 2). A total drainage area of Tuul River basin is $48868.4 \mathrm{~km}^{2}$ (Davaa, 2015).

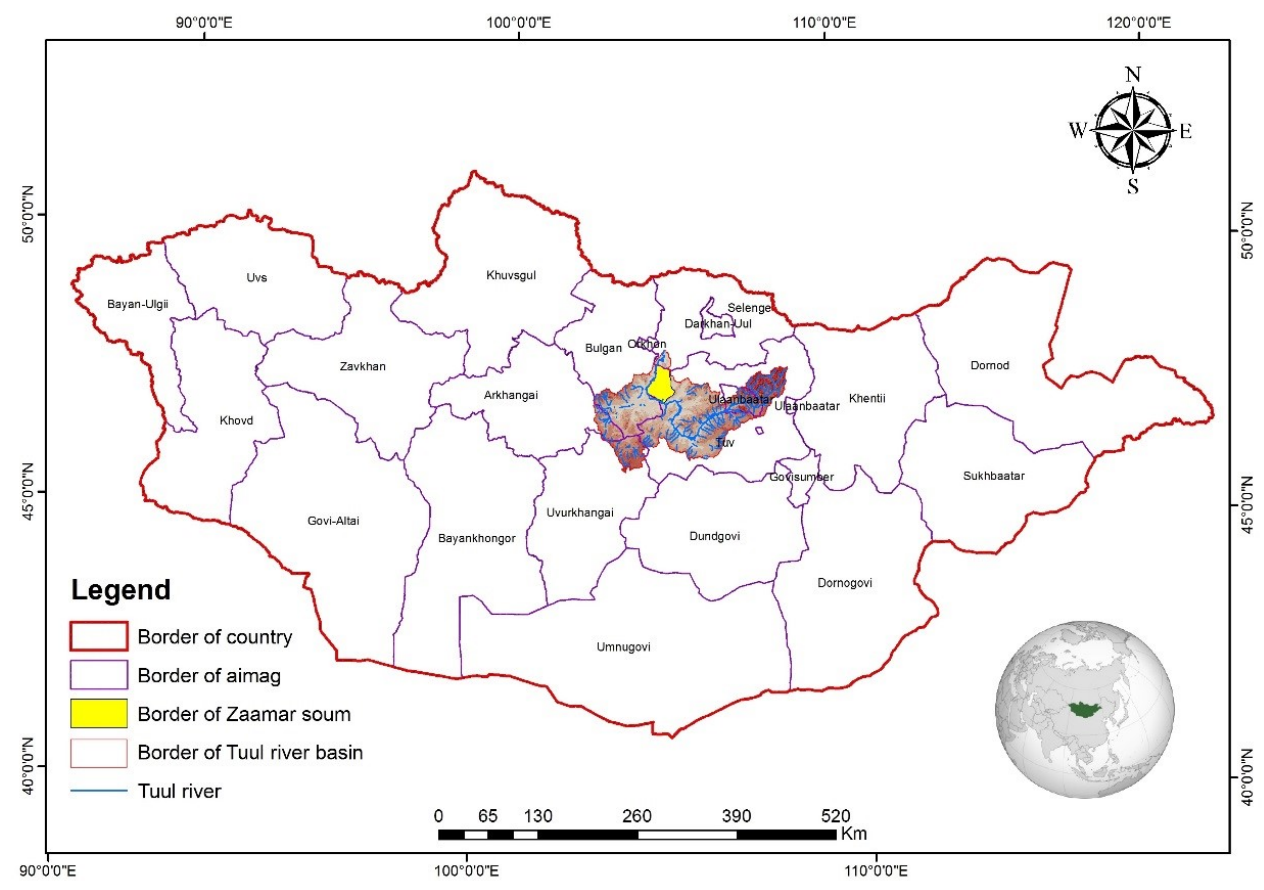

Figure 1. Geographic location of study area 
Even though Tuul River is one of main water sources which are included in the Pacific Ocean Basin, Tuul River is one of large rivers in Mongolia which feed Lake Baikal and rivers draining into the North Atlantic Ocean Basin. Revealing the anthropogenic effects on landforms in Tuul River basin is essential to protect regional water sources and to conserve ecological sustainability in the ocean basins. In this study landform evolution induced by human activity in Tuul River basin is considered.

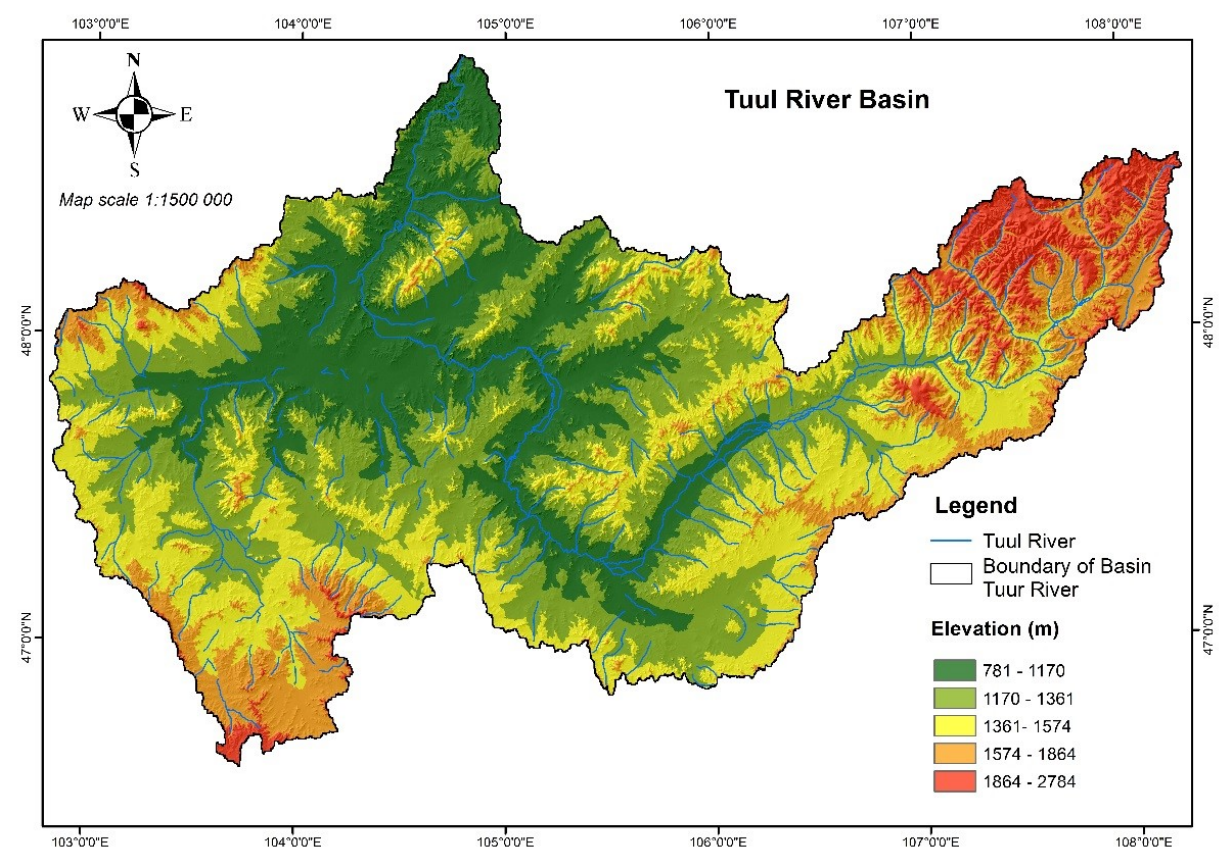

Figure 2. A drainage basin of Tuul River

MATERIALS AND METHODS

Changes of eroded land cover due to mining operation along the Tuul River in Zaamar soum, Tuv aimag are described in 2013 and 2017. For estimating the changes of eroded land cover, Sentinel-2 (05.16.2017) and Landsat-8 (06.23.2013) satellite image data are used and compiled on ArcGIS 10.2 and ENVI mapping programs.

\section{RESULTS AND DISCUSSION}

This study synthesizes previous results from scientific papers and reports and infers the anthropogenic landform evolution in the Tuul River basin.

Today more than 200 entities and private companies operate gold and construction raw materials such as gravels, sands and clays in Tuul River basin (Scientific report, 2013). Around Ulaanbaatar city and Zaamar soum in Tuv aimag (Fig. 1) become main centers for mining operation in the Tuul River basin.
Landforms in Tuul River basin in Zaamar soum are the most severely eroded due to mining. Because both sides of channel in Tuul River basin are affected by mining operation, the Tuul River basin is entirely eroded and its water resource is dropped. For instance, a channel of Tuul River is modified with $3.6 \mathrm{~km}$ and about 140 ha of its land is destroyed by gold-mining companies such as "Altan Dornod Mongol", "Mongol Gazar" and "Shijir Alt" (Scientific report, 2013).

\section{Landform evolution}

Landform evolution due to technical processes is classified as industrial, mining, settlements and others (Table 1), and these types are differed from each other with a frame to cover and a grade to affect. A similar study in mapping the land cover associated with the anthropogenic land uses of settlement and food production, as well as their complement in forest cover (Small and Sousa, 2016) has been done at global scales 
Table 1. Human activity on landform modification

\begin{tabular}{|l|l|l|}
\hline \multirow{2}{*}{ Type of land use } & \multicolumn{1}{|c|}{ Direct (landform structure) } & \multicolumn{1}{c|}{ Indirect (external processes) } \\
\cline { 2 - 4 } & \multicolumn{1}{|c|}{ Human impact } \\
\hline Sedentary entity & General overview of landform & Linear erosion and variation \\
\hline Agriculture & Linear positive and negative organisation & $\begin{array}{l}\text { Linear erosion, swamping, weed, degrada- } \\
\text { tion }\end{array}$ \\
\hline Hydrotechnique & $\begin{array}{l}\text { Deepened to environments opposing to } \\
\text { extensive landform }\end{array}$ & $\begin{array}{l}\text { Degradation, linear erosion, swamping, lake } \\
\text { deposits }\end{array}$ \\
\hline Mining operation & $\begin{array}{l}\text { Groundworks to establish well and depos- } \\
\text { its }\end{array}$ & $\begin{array}{l}\text { Gravitational force, linear erosion, degrada- } \\
\text { tion }\end{array}$ \\
\hline Overpopulation & Landform degradation and erosion & Collapse, landslide, gully \\
\hline Transportation & To establish dike and dam & Gully, rill, mass wasting, erosion, landslide \\
\hline
\end{tabular}

for depicting remote sensing of anthropogenic land cover and human-modified landscapes. In the floodplain of Tuul River near Ulaanbaatar settlements usually erode and modify the fluvial landforms. Moreover operation of gravels and sands exposes and digs land cover and pollutes river water. Main factor affecting erosion and degradation is mining area. For instance, mining companies along the beaches of Tuul River in Zaamar soum, Tuv aimag is the most influential one.

\section{Sedentary entity}

In Ulaanbaatar (Sonsgolon Bridge and Amgalan village) there are a numerous of mining companies operate to prepare the construction raw materials such as sands and gravels along beaches of Tuul River. Because the mining companies leave without any remediation after their operations, exposed valleys with $1.0-5.0 \mathrm{~m}$ deep holes and sinks are remained along the beaches without any condition for plantation and soil production (Scientific report, 2013).

There is a problem resulted from explorations of sands and gravels resulting in soil erosion in the Tuul River basin. Landforms in Shuvuun fabric village, the $13^{\text {th }}$ khoroo of Khan Uul district, Ulaanbaatar are shifted due to illegal explorations of sands and gravels (Fig. 3). The khoroo occupies 5672 ha territory and is bordered with the $12^{\text {th }}$ khoroo in the east, Songino Khairkhan district in the north and Altanbulag soum, Tuv aimag in the south.

The exploration cuts bushes, removes growing brushwoods and mixes soil profiles along the

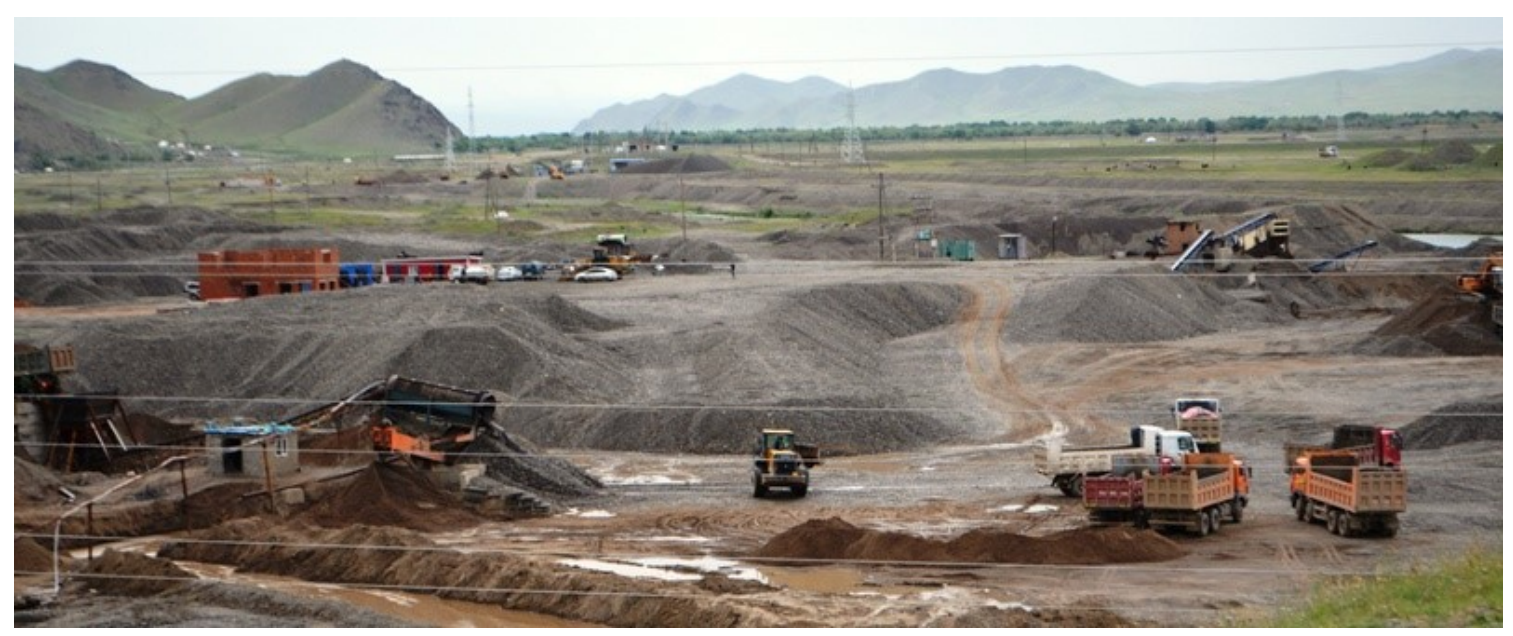

Figure 3. Mining operation in the Tuul River basin 


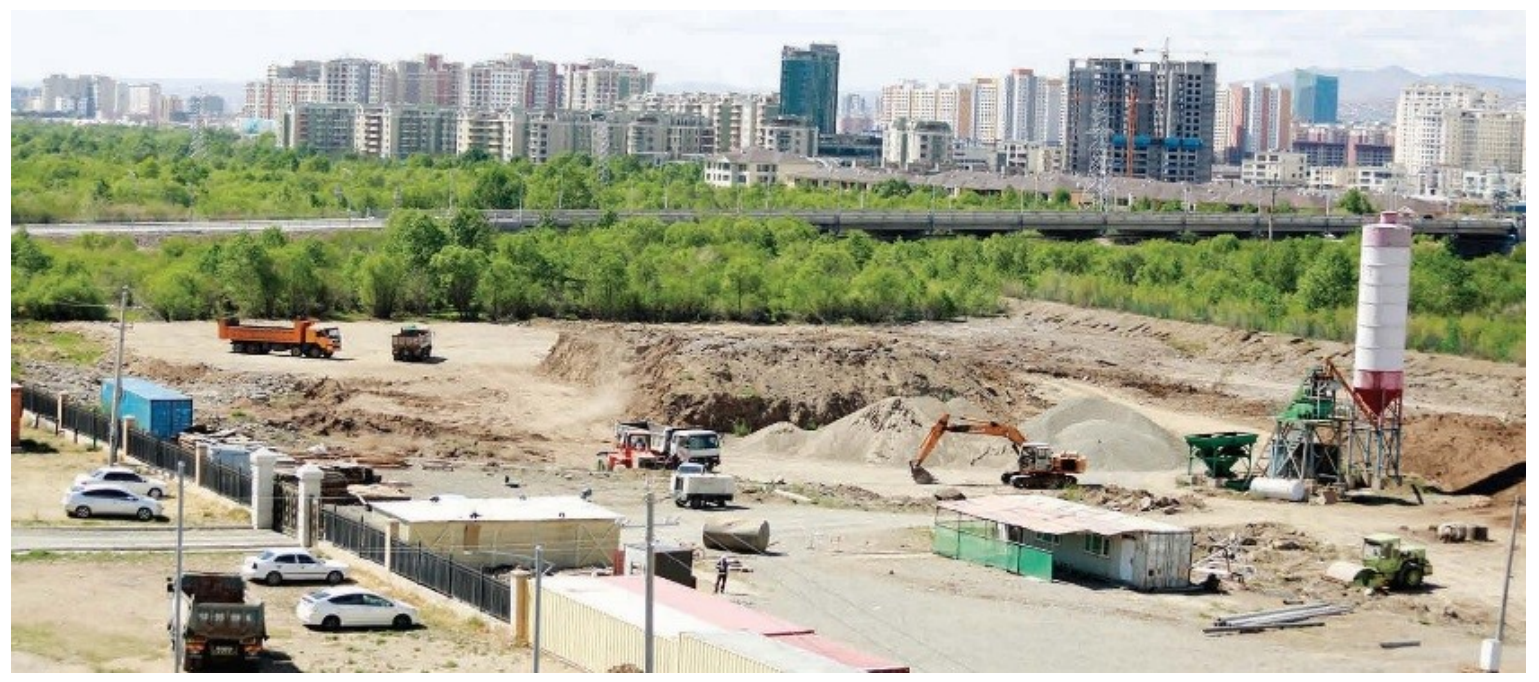

Figure 4. Floodplain erosion of Tuul River

beaches because apartments are illegally constructed on the bank of Tuul River (Fig. 4).

\section{Mining operation}

Landform is changed and land degradation is enlarged due to survey and exploration of mineral resources. For instance, mining operation in Zaamar soum, Tuv aimag has shifted landforms along the Tuul River (Figs.5, 6).

Accuracy of mapping describing landform changes near Zaamar soum in 2013 and 2017 based on Landsat and Sentinel satellite images shows that mountain forest and soil near soum
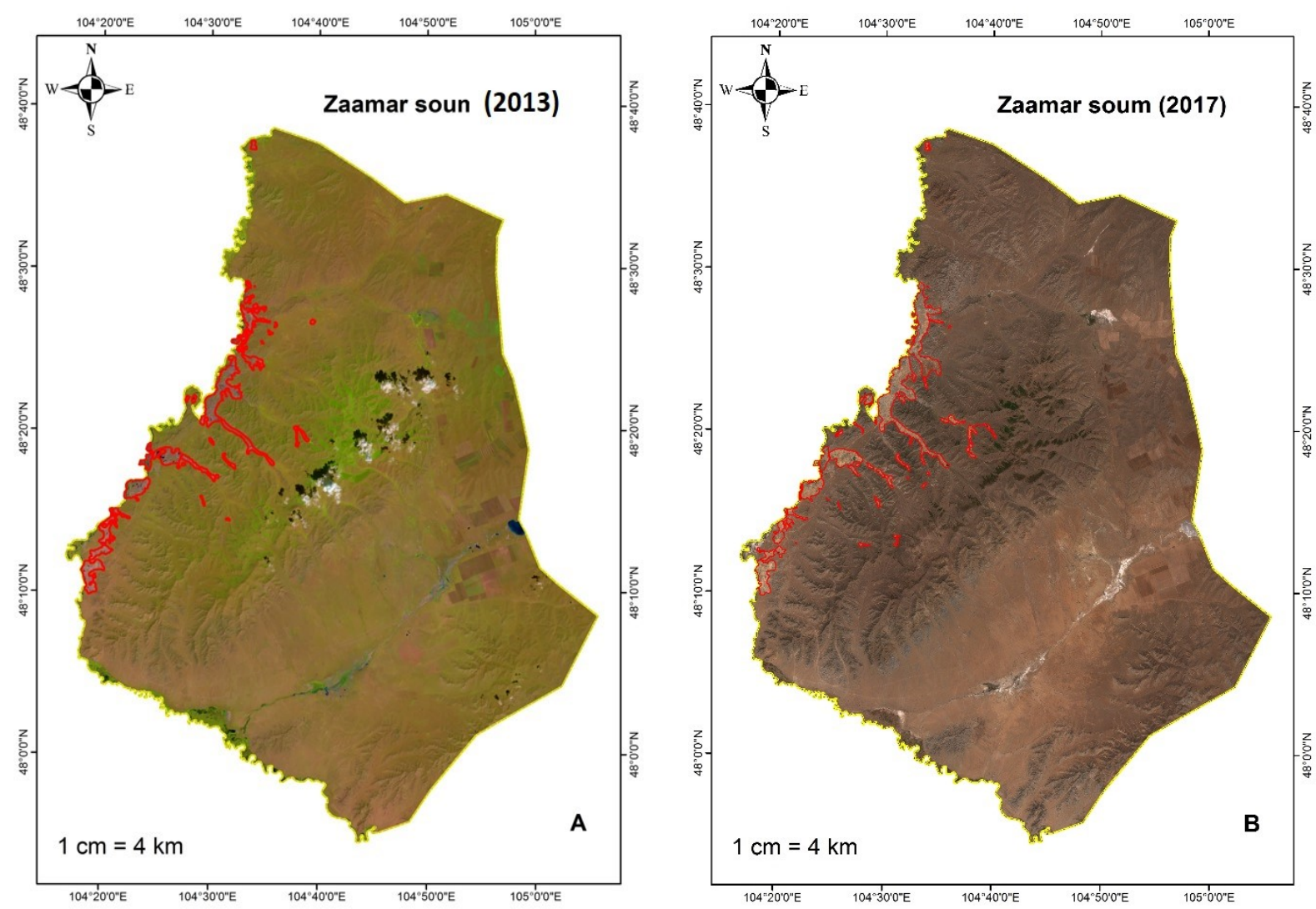

Figure 5. Landsat (A) and Sentinel (B) images of land cover in Zaamar soum in 2013 and 2017, respectively 
center have been distinctly changed and completely eroded due to mining operation (Fig. 5, Table 2). Table 2 shows that the eroded land cover was 4885 ha and 6442 ha in 2013 and 2017, respectively, i.e., total eroded land cover increased by $31 \%$ within the period.

There is a quarry of construction materials such as sands and gravels in Altanbulag soum, Tuv aimag locating in the middle part of the Tuul River basin, while gold deposits are explored in Zaamar soum locating in the downstream of Tuul River.

Survey and explorations of mineral resources by entities and companies are largely expanded with diverse ways each year. For instance, survey area of $4656.4 \mathrm{~km}^{2}$ occupies $9.4 \%$ of

Table 2. Degradation of gold deposits Zaamar area

\begin{tabular}{|c|c|c|}
\hline Date & 06.23 .2013 & 05.16 .2017 \\
\hline $\begin{array}{c}\text { Area of degraded } \\
\text { land cover (ha) }\end{array}$ & 4885 & 6442 \\
\hline
\end{tabular}

total area in the Tuul River basin, whereas exploration area of $339.3 \mathrm{~km}^{2}$ occupies $0.7 \%$ of total area in the Tuul River basin. Today these areas are completely destroyed. According to report of land cover database in 2010, land cover occupying 1247 ha was degraded due to exploration of mineral resources (Ministry of
Nature and Green Development, 2012).

Results from recent studies show inverse impacts on the environments due to illegal mining operations. For instance, feeding rivers of Tuul River such as Tsagaan bulag $(4.8 \mathrm{~km})$, Toson $(3.3 \mathrm{~km})$, Bayan $(5.5 \mathrm{~km})$, Ar Naimgan $(6.5 \mathrm{~km})$ and Khailaast $(10.7 \mathrm{~km})$ Rivers in Zaamar soum have been shrunk and their basins have been distinctly degraded. In addition, fertile soils and biomasses covering approximately $40 \mathrm{~km}$ of pasture and $31380.2 \mathrm{ha}$ of meadow are lost in the Tuul River basin. Landscapes with area of 5761.3 ha of channel, floodplain and terraces of Tuul River were completely eroded (Ministry of Nature and Green Development, 2012).

\section{CONCLUSION}

It is required to control the illegal mining operation, construction and industrialization in protection zones within Tuul River basin and to remediate its degraded land cover in/around floodplain. Channel modification and reduction in water level are strengthened due erosion and degradation induced by human activity. Moreover, water pollution of Tuul River affects human health. It is needed to estimate precise environmental study and to implement legal rules in the Tuul River basin.

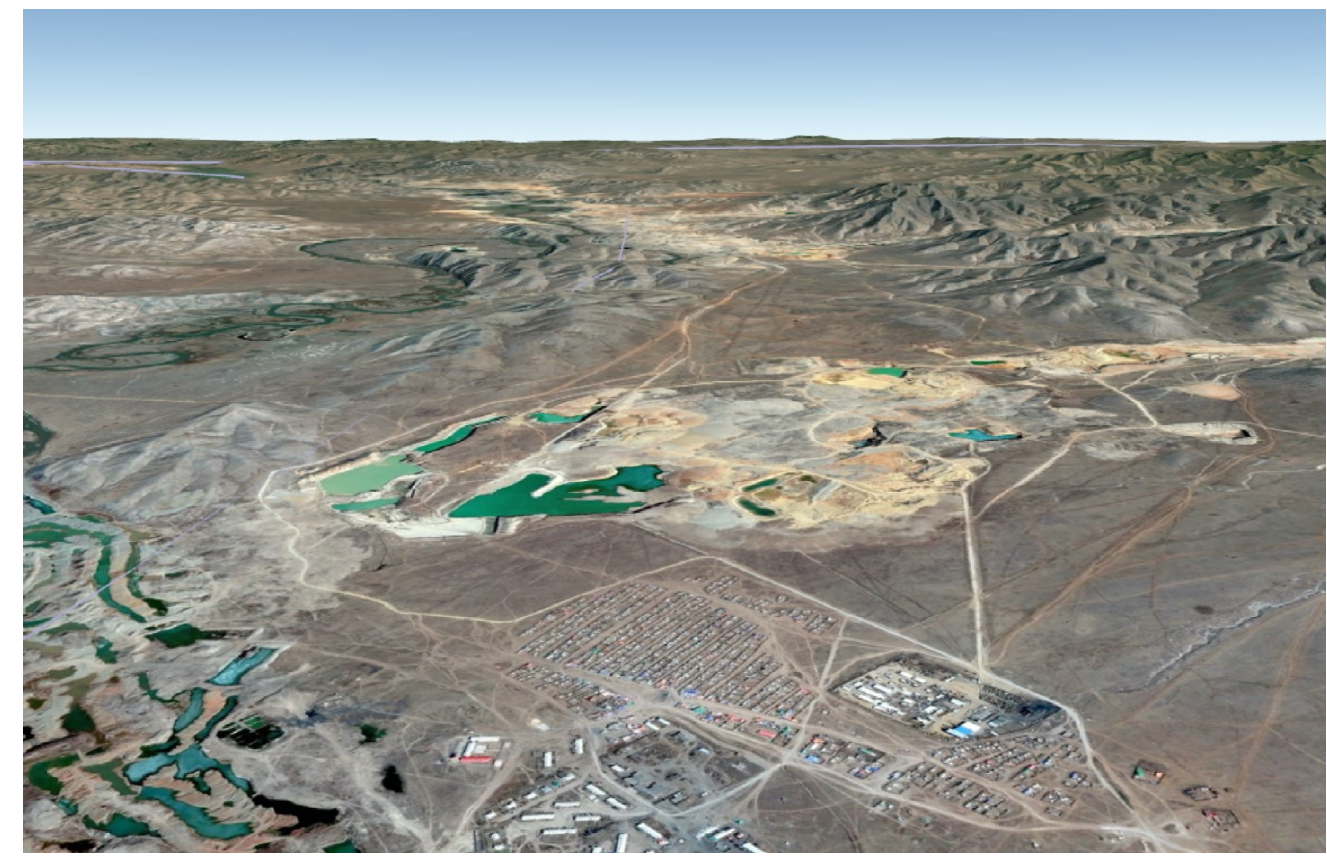

Figure 6. Mining exploration in Zaamar soum 


\section{REFERENCES}

Bai, X., Leeuw, S., O’Brien, K., Berkhout, F., Biermann, F., Brondizio, E.S., Cudennec, C., Dearing, J., Duraiappah, A., Glaser, M., Revkin, A., Steffen, W., Syvitski, J. 2016. Plausible and desirable futures in the Anthropocene: A new research agenda. Global Environmental Change 39, 351-362.

Biermann, F., Bai, X., Bondre, N., Broadgate, W., Chen, C.A., Dube, O.P., Erisman, J.W., Glaser, M., Hel, S., Lemos, M.C., Seitzinger, S., Seto, K.C. 2016. Down to Earth: Contextualizing the Anthropocene. Global Environmental Change 39, 341-350.

Brondizio, E.S., O’Brien, K., Bai, X., Biermann, F., Steffen, W., Berkhout, F., Cudennec, C., Lemos, M.C., Wolfe, A., Oliveira, J.P., Chen, C.A. 2016. Re-conceptualizing the Anthropocene: A call for collaboration. Global Environmental Change 39, 318-327.

Brown, A.G., Tooth, S., Bullard, J.E., Thomas, D.S.G., Chiverrell, R.C., Plater, A.J., Murton, J., Thorndycraft, V.R., Tarolli, P., Rose, J., Wainwright, J., Downs, P., Aalto, R. 2016. The geomorphology of the Anthropocene: emergence, status and implications. Earth Surface Processes Landforms. John Wiley \& Sons, Ltd. doi: 10.1002/esp.3943.

Davaa, G. 2015. Surface water of Mongolia. Ulaanbaatar, Mongolia. p.136.

Fernández-Giménez, M.E., Venable, N.H., Angerer, J., Fassnacht, S.R., Reid, R.S., Khishigbayar, J. 2017. Exploring linked ecological and cultural tipping points in Mongolia. Anthropocene 17, 46-69.

Gałuszka, A., Migaszewski, Z.M., Namiesnik, J. 2017. The role of analytical chemistry in the study of the Anthropocene. Trends in Analytical Chemistry 97, 146-152.

Lockie, S. 2017. A better Anthropocene? Environmental Sociology 3 (3), 167-172. doi: 10.1080/23251042.2017.1357096.

Ministry of Nature and Green Development. 2012. Planning of integrated management in a drainage basin of Tuul River. p.220.

National Atlas. 2009. Institute of Geography, Mongolian Academy of Sciences.

Scientific report of complete investigation on physical geography of central Mongolia. 2013. Division of Physical Geography,
Institute of Geography, Mongolian Academy of Sciences, Ulaanbaatar, Mongolia. p. 185186.

Small, C., Sousa, D., 2016. Humans on Earth: Global extents of anthropogenic land cover from remote sensing. Anthropocene 14, 1-33.

Syvitski, J.P. 2018. The Anthropocene - from Concept, to Geological Epoch, to 21st Century Science. 20th International Sedimentological Congress (ISC), Quebec City, Canada.

Tarolli, P., Preti, F., Romano, N. 2014. Terraced landscapes: From an old best practice to a potential hazard for soil degradation due to land abandonment. Anthropocene 6, 10-25. doi: 10.1016/j.ancene.2014.03.002.

Veland, S., Lynch, A.H. 2016. Scaling the Anthropocene: How the stories we tell matter. Geoforum 72, 1-5. doi: 10.1016/ j.geoforum.2016.03.006.

Verburg, P.H., Dearing, J.A., Dyke, J.G., Leeuw, S., Seitzinger, S., Steffen, W., Syvitski, J. 2016. Methods and approaches to modelling the Anthropocene. Global Environmental Change 39, 328-340.

Waters, C.N., Zalasiewicz, J., Summerhayes, C., Barnosky, A.D., Poirier, C., Gałuszka, A., Cearreta, A., Edgeworth, M., Ellis, E.C., Ellis, M., Jeandel, C., Leinfelder, R., McNeill, J.R., Richter, D.B., Steffen, W., Syvitski, J., Vidas, D., Wagreich, M., Williams, M., An, Z., Grinevald, J., Odada, E., Oreskes, N., Wolfe, A.P. 2016. The Anthropocene is functionally and stratigraphically distinct from the Holocene. Science: Earth History 351 (6269), 137-149. doi: $10.1126 /$ science.aad2622.

Waters, C.N., Wagreich, M., Zalasiewicz, J., AWG (Anthropocene Working Group). 2018. Global Boundary Stratotype Section and Point (GSSP) for the Anthropocene Series: Where and how to look for potential candidates. EGU General Assembly. Geophysical Research Abstracts 20, EGU2018-4590.

Williams, M., Zalasiewicz, J., Waters, C.N., Edgeworth, M., Bennett, C., Barnosky, A.D., Ellis, E.C., Ellis, M.A., Cearreta, A., Haff, P.K., Ivar do Sul, J.A., Leinfelder, R., McNeill, J.R., Odada, E., Oreskes, N., 
Revkin, A., Richter, D.B., Steffen, W., Summerhayes, C., Syvitski, J.P., Vidas, D., Wagreich, M., Wing, S.L., Wolfe, A.P., An, Z. 2016. The Anthropocene: a conspicuous stratigraphical signal of anthropogenic changes in production and consumption across the biosphere. Earth Future 4. 1-20. doi: 10.1002/2015EF000339.

Zalasiewicz, J., Waters, V.N., Ivar do Sul, J.A., Corcoran, P,L., Barnosky, A.D., Cearreta, A., Edgeworth, M., Gałuszka, A., Jeandel, C., Leinfelder, R., McNeill, J.R., Steffen, W., Summerhayes, C., Wagreich, M., Williams, M., Wolfe, A.P., Yonan, Y. 2016. The geological cycle of plastics and their use as a stratigraphic indicator of the Anthropocene. Anthropocene 13, 4-17.

Zalasiewicz, J., Waters, C.N., Wolfe, A.P., Barnosky, A.D., Cearreta, A., Edgeworth, M., Ellis, E.C., Fairchild, I.J., Gradstein, F.M., Grinevald, J., Haff, P., Head, M.J., Ivar do Sul, J.A., Jeandel, C., Leinfelder, R., McNeill, J.R., Oreskes, N., Poirier, C., Revkin, A., Richter, D., Steffen, W., Summerhayes, C., Syvitski, J.P.M., Vidas, D., Wagreich, M., Wing, S., Williams, M. 2017. Making the case for a formal Anthropocene Epoch: an analysis of ongoing critiques. Newsletters on Stratigraphy. 206227. doi: $10.1127 / \operatorname{nos} / 2017 / 0385$. 